\title{
Pigeon pea (Cajanus cajan) fodder cutting management in the Guinea Savanna Agro-Ecological Zone of Ghana
}

\author{
E. A. Tenakwa $\cdot$ A. Z. Imoro $\cdot$ T. Ansah $(10)$ F. Kizito
}

Received: 27 May 2021/Accepted: 3 September 2021 / Published online: 23 September 2021

(C) The Author(s) 2021

\begin{abstract}
This study evaluated the effect of cutting regime on biomass yield and nutrient composition of pigeon pea (Cajanus cajan (L) Millsp.) fodder in the Guinea Savanna Agro-Ecological Zone of Ghana. Three cutting regimes (12, 16 and 20 Week After Planting [WAP]) in RCBD were imposed on Cajanus cajan at both initial establishment and regrowth. At each harvest, biomass yield was estimated after which samples of the fodder were separated into leaf and stem botanical fractions for chemical composition and in vitro digestibility. Cutting regime significantly affected plant height, number of branches and stem diameter in both the initial establishment and regrowth. Biomass yield was significantly affected by cutting regime in the initial establishment but not the regrowth. The biomass yield was highest in the harvest at 20WAP $(6515 \mathrm{kgDM} / \mathrm{ha})$ while $12 \mathrm{WAP}$
\end{abstract}

E. A. Tenakwa · T. Ansah ( $\square)$

Faculty of Agriculture, Food and Consumer Sciences, Department of Animal Science, University for

Development Studies, P. O. Box 1882, Tamale, Ghana

e-mail: tansah@uds.edu.gh

\section{A. Z. Imoro}

Faculty of Natural Resources and Environment, Department of Biodiversity Conservation and Management, University for Development Studies, P. O. Box 1882, Tamale, Ghana

\section{F. Kizito}

International Institute of Tropical Agriculture, Tamale, Ghana
(3175 kg/ha) recorded the lowest biomass yield in the initial establishment. All chemical composition parameters were significantly affected by cutting regime and botanical fractions except hemicellulose in the initial establishment. Cutting regime also significantly affected DM, CP and ash concentrations in the regrowth with botanical fraction significantly $(P<0.05)$ influencing $\mathrm{CP}, \mathrm{NDF}, \mathrm{ADF}$ and ash. The highest $\mathrm{CP}$ was obtained in the leaf fraction harvested at $12 \mathrm{WAP}$ and $20 \mathrm{WAP}$ in the initial establishment and regrowth respectively. Cutting regime, botanical fraction and their interaction were significant in gas produced at $24 \mathrm{~h}$, SCFA and ME in both the initial establishment and regrowth stages. In conclusion, harvest at 20WAP produced the highest biomass yield but lower CP in the initial establishment whiles in the regrowth, harvest at 20WAP produced higher biomass yield, CP and ME.

Keywords Crude protein - Cutting regime . Digestibility $\cdot$ Fodder $\cdot$ Pigeon pea $\cdot$ In vitro gas

\section{Introduction}

Pigeon pea (Cajanus cajan), is a perennial leguminous crop with several uses: grain, vegetable, animal feed, green manure, and firewood (Gowda et al. 2012). It is one of the best drought-resistant legumes (Bidlack 
et al. 2006) and is often the only grain plant that provides some grain yield for the period of dry spells when other legumes such as field beans have wilted and possibly dried up (Sharma et al. 2011). The plant has an erect growth pattern, it is a short-lived perennial leguminous shrub with a height of about 1-2 $\mathrm{m}$, but can reach up to 2-5 $\mathrm{m}$ high (Bekele-Tessema 2007).

Fodder from Cajanus cajan has been reported to increase the intake of low-quality fodder and enhances ruminant live weight due to its relatively higher nitrogen concentration (Shenkute et al. 2013). Pigeon pea fodder may be used in ruminant diets as a protein supplement even at higher levels of inclusion without any detrimental effect. The fodder is highly digestible and supply high quality protein when fed to ruminants (Corriher et al. 2007). Sheep and goats in Ghana, have been found to select leaves of Pigeon pea in preference to other legumes (Karbo et al. 1998).

The cultivation of Pigeon pea as fodder, despite its forage potential, is not a common practice amongst smallholder farmers in Ghana. Pigeon pea is rather cultivated either as a border crop or on marginal lands for grains, fodder and fuel wood (Marfo 1990). At maturity, the pods are harvested and threshed to separate the grain from the husk. The husk, combined with dry leaves of the Pigeon pea are fed to ruminants (Agyare et al. 2002) by smallholder farmers practicing the crop/livestock production system. This makes Pigeon pea a very useful crop in the crop/livestock production system in Ghana.

Tolerance to grazing or cutting is a very important consideration in selecting a plant for fodder production. Karbo et al. (1998), investigated the effect of pruning at 11 and 16 weeks after planting on fodder yield of pigeon pea and reported higher average yields (1.440-1.412 kg DM/row) in the late harvest compared to the early harvest $(0.084-0.660 \mathrm{~kg} \mathrm{DM} / \mathrm{row})$. However, this study was limited to the biomass yield in the initial establishment with no data on the effect of the cutting on the regrowth. Regrowth after cutting in legumes is dependent on mobilization of carbohydrates reserves stored mainly in the roots and other subterranean parts of the plant and also the available photosynthetic active organs (Wolfson 2000). The interval between planting and harvest may significantly affect the concentration of carbohydrate reserves and subsequently the ability of the plant to regrow after cutting. In addition the extent of defoliation, whether total or partial defoliation may also affect the potential regrowth period and biomass yield. Information on the effect of harvesting (cutting) Pigeon pea fodder in both the initial establishment and regrowth on biomass yield, nutritional composition and digestibility in the Guinea Savannah AgroEcological Zone of Ghana is scanty. Additionally, cutting as a farm operation can have implications on labor distribution dynamics for households especially in farming systems where labor is scarce with increasing demands arising from diversified farming activities. This study was therefore undertaken to determine the effect of different harvesting regimes on the growth, yield and chemical composition, in vitro gas, short chain fatty acid and metabolizable energy of pigeon pea in the savannah ecological zone of Ghana.

\section{Materials and methods}

\section{Study area}

This research was conducted at the Horticulture experimental field at Nyankpala Campus of the University for Development Studies. Nyankpala campus is in the Tolon District of the Northern Region of Ghana within the Guinea Savanna Agro-Ecological Zone. Geographically, Nyankpala campus falls within latitude $9^{\circ} 24^{\prime} \mathrm{N}$ and longitude $0^{\circ} 59^{\prime} \mathrm{W}$. Nyankpala is $16 \mathrm{~km}$ (10 miles) away from Tamale, the capital of Northern region with an altitude of $167 \mathrm{~m}$ above sea level. The study area has mean annual rainfall of $1043 \mathrm{~mm}$ distributed fairly from April to late November. Temperatures generally fluctuate between $15{ }^{\circ} \mathrm{C}$ (minimum) and $42{ }^{\circ} \mathrm{C}$ (maximum) with a mean annual temperature of $28.5^{\circ} \mathrm{C}$. The mean annual relative humidity at day time is $54 \%$.

Source of planting materials and land preparation

Local varieties of Cajanus cajan seeds commonly found growing in the northern zone of Ghana were procured from the market and used for the study. Poultry manure was incorporated on the field at a rate of $0.4 \mathrm{~kg} / \mathrm{m}^{2}$ and ploughed. The Cajanus cajan seeds were planted at stake at about $4 \mathrm{~cm}$ deep in the soil at a planting distance of $0.5 \mathrm{~m}^{*} 0.5 \mathrm{~m}$. 


\section{Experimental design and data collection}

The field was divided into eighteen (18) plots with each plot measuring $15 \mathrm{~m}^{2}(5 \mathrm{~m} \times 3 \mathrm{~m})$. Three treatments in the initial establishment and three treatments in the regrowth were assigned to the plots in a Randomized Complete Block Design. The treatments in the initial establishment were: Cutting at 12 weeks after planting (C12); Cutting at 16 weeks after planting (C16); Cutting at 20 weeks after planting (C20). The treatments in regrowth were Cutting at 12 weeks after regrowth (RC12); Cutting at 16 weeks after regrowth (RC16); Cutting at 20 weeks after regrowth (RC20).

Germination was observed four (4) days after planting. Five (5) plants were randomly selected on each plot (excluding those on the borders) on which plant height, number of branches and stem girth were taken starting from the sixth week after planting. This was to ensure that the plants were firmly rooted for growth and also to avoid breakages and damages to the weak stems. Plant height was measured from the base to the tip of the plant with a measuring tape whiles stem girth was taken from the base of the selected plant using veneer caliper. Number of branches was recorded by simple arithmetic counting. The entire plants on each plot were harvested at 12,16 and 20 WAP using a machete at a height of $50 \mathrm{~cm}$ above ground and the total harvest per plot was weighed. Sub-samples $(200 \mathrm{~g})$ were taken from each plot, chopped into short lengths $(2-5 \mathrm{~cm})$ and oven dried at $60{ }^{\circ} \mathrm{C}$ for $48 \mathrm{~h}$ (AOAC 1990). Biomass yield of each plot was calculated on dry matter basis by multiplying the percentage dry weight of the subsamples from the above ground biomass to the fresh weight of the harvest from each plot.

Sub-samples of the harvest from each plot was divided into stem and leaf botanical fractions. These were chopped into smaller pieces to facilitate drying and milling. The chopped samples were milled using a Hammer mill (Brabender, Germany) to pass through a $2 \mathrm{~mm}$ and then $1 \mathrm{~mm}$ sieve screen sequentially for laboratory analysis (AOAC 1990).

A $3 \times 2$ factorial design in Randomized Complete Block was used for the chemical and in vitro gas analysis. The factors included cutting regimes of 12 , 16 and $20 \mathrm{WAP}$ and two botanical fractions which were leaf and stem. The AOAC (1990) procedure was used in the determination of crude protein $(\mathrm{CP})$ and ash. NDF and ADF were determined limited of residual ash through sodium sulfite and $\alpha$ - amylase using the procedure of Van Soest et al. (1991) and this was done using Ankom ${ }^{200}$ fibre analyser (Method 5 for ADF and method 6 for NDF).

The batch in vitro gas production technique of Theodorou et al. (1994) was adopted with some modification in the source of rumen fluid (Ansah et al., 2018) to evaluate the $24 \mathrm{~h}$ gas production. Rumen fluid was obtained from four (4) slaughtered Sanga cattle $(300 \pm 15 \mathrm{~kg})$ at the Tamale abattoir. The cattle were managed on naturally growing indigenous heterogamous pasture field. The rumen fluid was filtered through double layer cheese cloth with continuous supply of carbon dioxide. McDoughal's buffer was prepared and kept warm in a water bath $\left(39{ }^{\circ} \mathrm{C}\right)$. The rumen fluid and the buffer were mixed in a ratio of 1: 4 under continuous supply of Carbon dioxide to get the incubation media. Approximately $200 \mathrm{mg}$ of the milled forage sample was weighed into a $50 \mathrm{ml}$ test tube with five replicates per treatment in two separate batch cultures. About $30 \mathrm{ml}$ of the warm and anaerobic incubation media was dispensed into the test tubes and incubated in a water bath. The pressure (gas production) in the test tubes as a result of microbial fermentation was measured with a digital manometer at $24 \mathrm{~h}$ and used for the computation of digestible organic matter (DOM) and metabolizable energy (ME). The DOM was calculated using the equation $\mathrm{DOM}(\%)=16.49+0.9042 \mathrm{GP}+0.0492 \mathrm{CP}+$ 0.0387 ash whiles SCFA and metabolizable energy were calculated using the equations SCFA $=0.0239^{*}$ GP*0.0601 and ME $(\mathrm{MJ} / \mathrm{kg} \quad \mathrm{DM})=14.30$ $(0.0134 * \mathrm{ADF})$ respectively by Menke and Steingass (1988).

\section{Data analysis}

The data on biomass yield, plant height, number of branches and stem diameter were analysed with the analysis of variance (ANOVA) from Genstat 11th edition (Payne et al., 2008). The in vitro gas digestibility trial and chemical composition parameters were analysed as two-way ANOVA. F-test means which were significant at $5 \%$ were separated using Tukey HSD. 


\section{Results}

Growth and biomass yield of Cajanus cajan

Plant height of Cajanus cajan at different cutting regimes is shown in Fig. 1a. The plants at 12WAP were the shortest in the initial establishment with no significant difference between the plants harvested at 16WAP and 20WAP. In the regrowth, plants at 12 and 20 WAP were found to be significantly taller than the 16 WAP.

Figure $1 \mathrm{~b}$ shows the number of branches of Cajanus cajan at different cutting regimes. Plants cut at 16WAP had significantly higher number of branches in the initial establishment while no significant difference existed in plants harvested at 12WAP and 20WAP. For the regrowth however, plants harvested at 12WAP recorded higher number of branches with significant difference observed between plants harvested at 12WAP, 16WAP and 20WAP.

The stem diameter of Cajanus cajan at different cutting regime is shown in Fig. 1c. The highest mean stem diameter was recorded in the plants cut at 16WAP while plants harvested at 12WAP recorded the least stem diameter in the initial establishment. The regrowth followed similar trend where plants harvested at 12 WAP recorded significantly lower stem diameters compared to those harvested 16WAP.
Fig. 1 a Plant height of Cajanus cajan at three harvest stages of initial establishment and regrowth having SEM as error bars. b Number of branches of Cajanus cajan at three harvest stages of initial establishment and regrowth (SEM, error bars). Bars with different letters represent significant difference at $P<0.05 . c$ Stem diameter of Cajanus cajan at three harvest stages of initial establishment and regrowth (SEM, error bars). Bars with different letters represent significant difference at $P<0.05 . d$ Biomass yield of Cajanus cajan at three harvest stages of initial establishment and regrowth (SEM, error bars). Bars with different letters represent significant difference at $P<0.05$
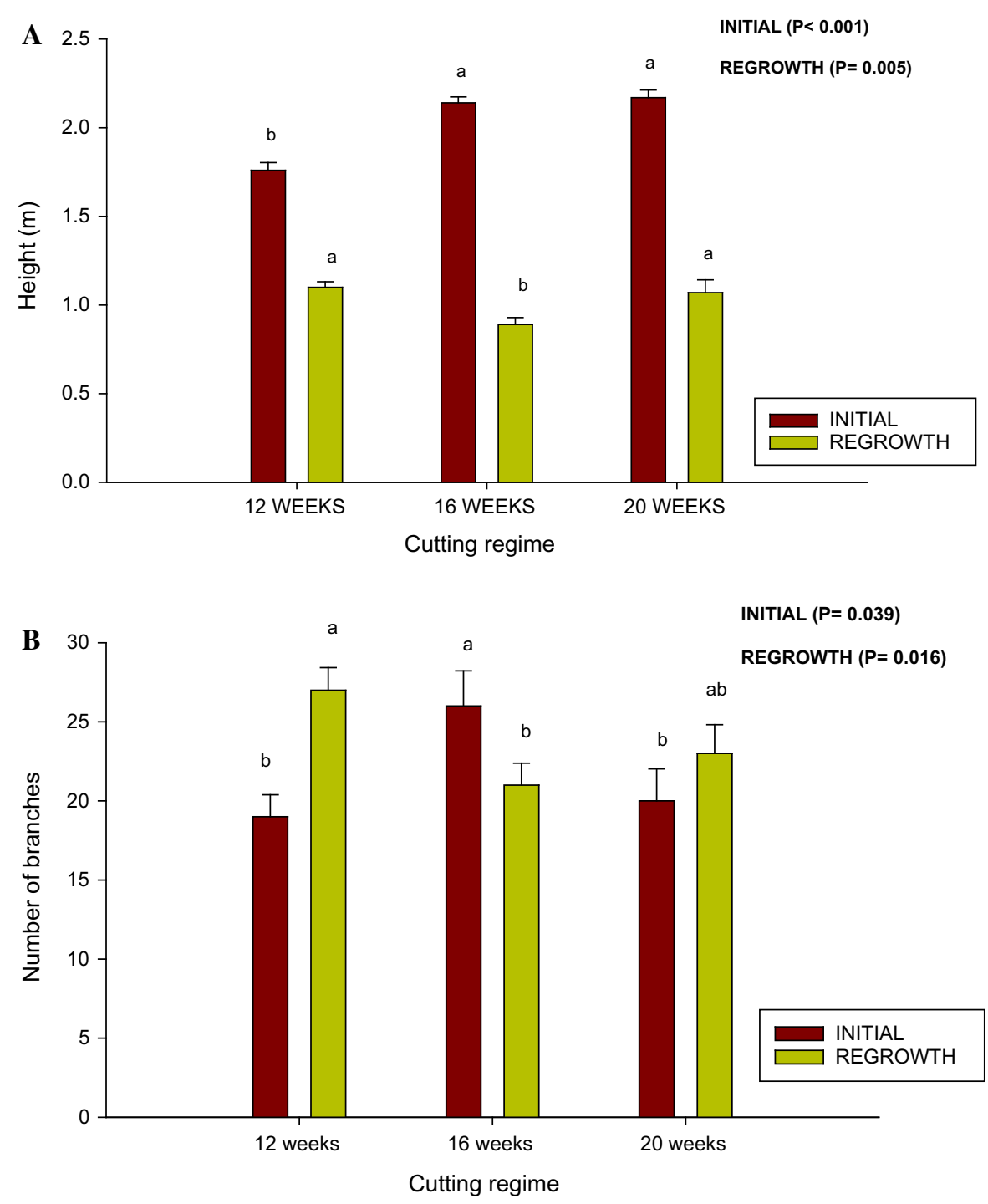

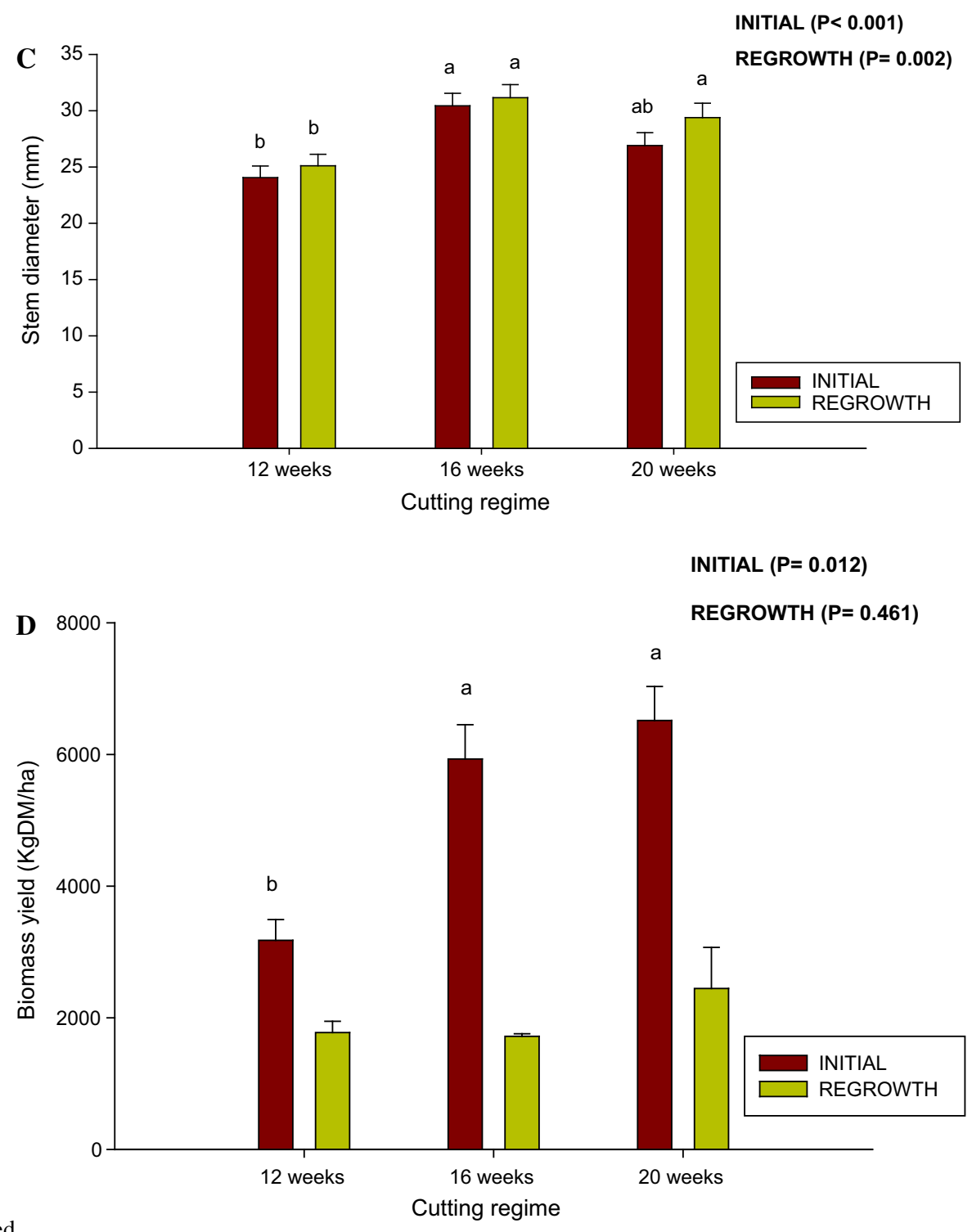

Fig. 1 continued

Figure 1d shows the biomass yield of Cajanus cajan at different cutting regimes. Harvesting at 20 WAP yielded the most biomass $(6515 \mathrm{~kg} / \mathrm{ha})$ with the least obtained in 12 WAP $(3175 \mathrm{~kg} / \mathrm{ha})$ in the initial establishment. There were no significant differences between plants harvested at 16 WAP and 20 WAP. In the regrowth, harvesting at 20 WAP had the most biomass with no significant difference $(P=0.461)$ between the cutting regimes.

\section{Chemical composition and In vitro digestibility}

The chemical composition of Cajanus cajan harvested at different cutting regimes after initial establishment is shown in Table 1. There was a significant two-way interaction effect of cutting regime and botanical fraction on $\mathrm{CP}, \mathrm{ADF}$ and ash. The highest $\mathrm{CP}$ $(235.8 \mathrm{~g} / \mathrm{Kg} \mathrm{DM})$ was obtained in the leaf fraction harvested at $12 \mathrm{WAP}$ while the least $(89.1 \mathrm{~g} / \mathrm{Kg} \mathrm{DM})$ was recorded in the stem fraction harvested at $20 \mathrm{WAP}$ in the initial establishment. The NDF and ADF increased as the cutting regime increased with higher 
Table 1 Chemical composition of Cajanus cajan as influenced by cutting regime on dry matter basis (g/kgDM) at initial establishment

\begin{tabular}{|c|c|c|c|c|c|c|c|}
\hline \multirow[t]{2}{*}{ Cutting regime } & \multirow[t]{2}{*}{ Botanical fraction } & \multicolumn{6}{|c|}{ Parameters (g/kgDM) } \\
\hline & & $\mathrm{DM}$ & $\mathrm{CP}$ & NDF & ASH & $\mathrm{ADF}$ & HEM \\
\hline \multirow[t]{2}{*}{ C 12} & Leaf & 273.3 & $235.8^{\mathrm{a}}$ & 470.8 & $70^{\mathrm{a}}$ & $298^{\mathrm{d}}$ & 172.8 \\
\hline & Stem & 279.3 & $133.9^{\mathrm{d}}$ & 599.8 & $45^{\mathrm{d}}$ & $466.6^{\mathrm{b}}$ & 133.2 \\
\hline \multirow[t]{2}{*}{ C 16} & Leaf & 396.7 & $234.3^{\mathrm{b}}$ & 485.3 & $55^{\mathrm{c}}$ & $330.1^{\mathrm{c}}$ & 155.2 \\
\hline & Stem & 424.6 & $126.4^{\mathrm{e}}$ & 622.6 & $60^{\mathrm{b}}$ & $462.3^{\mathrm{b}}$ & 160.4 \\
\hline \multirow[t]{2}{*}{ C 20} & Leaf & 465.9 & $184.4^{\mathrm{c}}$ & 434.0 & $60^{\mathrm{b}}$ & $292.5^{\mathrm{d}}$ & 141.5 \\
\hline & Stem & 491.9 & $89.1^{\mathrm{f}}$ & 631.0 & $45^{\mathrm{d}}$ & $495.1^{\mathrm{a}}$ & 135.9 \\
\hline S. e. d & & 10.98 & 0.31 & 13.23 & 0,05 & 6.57 & 16.10 \\
\hline \multirow[t]{3}{*}{$P$ value } & Cutting regime & $<.001$ & $<.001$ & 0.019 & $<.001$ & 0.023 & 0.25 \\
\hline & Fraction & 0.010 & $<.001$ & $<.001$ & $<.001$ & $<.001$ & 0.21 \\
\hline & Cutting regime $\mathrm{x}$ Fraction & 0.334 & $<.001$ & 0.351 & $<.001$ & 0.002 & 0.26 \\
\hline
\end{tabular}

${ }^{a}$ Means in the same column with different superscript are significantly different at $\mathrm{P}<0.05, \mathrm{CP}=\mathrm{Crude}$ Protein, DM $=$ Dry Matter, NDF $=$ Neutral Detergent Fibre, ADF $=$ Acid Detergent Fibre, HEM $=$ Hemicellulose

concentrations recorded in the stem fractions than the leaf.

In the regrowth, the two-way interaction effect of cutting regime and botanical fraction significantly affected CP and ash whilst DM, NDF and ADF were only affected by the main effect of cutting regime or botanical fraction (Table 2). The highest CP was obtained in the leaf fraction of the harvest at 20 WAP with the least obtained in the stem fraction of the harvest at $20 \mathrm{WAP}$. The $\mathrm{CP}$ in the leaf fraction declined marginally from the 12WAP to 16WAP but with higher percentage $(21 \%)$ decline at 20 WAP. The trend was similar for the stem fraction. The dry matter was significantly influenced by cutting regime with the harvest at 12 WAP having the highest and the least reordered in the harvest at $16 \mathrm{WAP}$. The NDF and ADF were significantly affected by botanical fraction.

Table 2 Chemical composition of Cajanus cajan as influenced by cutting regime on dry matter basis (g/kgDM) at regrowth

\begin{tabular}{|c|c|c|c|c|c|c|c|}
\hline \multirow[t]{2}{*}{ Cutting regime } & \multirow[t]{2}{*}{ Botanical fraction } & \multicolumn{6}{|c|}{ Parameters (g/kgDM) } \\
\hline & & DM & $\mathrm{CP}$ & $\mathrm{NDF}$ & ASH & $\mathrm{ADF}$ & HEM \\
\hline \multirow[t]{2}{*}{ RC 12} & Leaf & 453.5 & $163.5^{\mathrm{b}}$ & $422.9^{\mathrm{b}}$ & $70^{\mathrm{c}}$ & $287.8^{\mathrm{b}}$ & 135.0 \\
\hline & Stem & 459.9 & $127.3^{\mathrm{d}}$ & $564.3^{\mathrm{a}}$ & $50^{\mathrm{f}}$ & $386.1^{\mathrm{ab}}$ & 178.2 \\
\hline \multirow[t]{2}{*}{$\mathrm{RC} 16$} & Leaf & 384.2 & $154.2^{\mathrm{c}}$ & $471.1^{\mathrm{ab}}$ & $90.1^{\mathrm{a}}$ & $326.7^{\mathrm{ab}}$ & 144.5 \\
\hline & Stem & 397.1 & $100.4^{\mathrm{e}}$ & $554.3^{\mathrm{a}}$ & $60.1^{\mathrm{e}}$ & $445.5^{\mathrm{a}}$ & 118.8 \\
\hline \multirow[t]{2}{*}{ RC 20} & Leaf & 413.9 & $194^{\mathrm{a}}$ & $409.1^{\mathrm{b}}$ & $80^{\mathrm{b}}$ & $266.3^{\mathrm{b}}$ & 142.8 \\
\hline & Stem & 448.0 & $80.8^{\mathrm{f}}$ & $553.5^{\mathrm{a}}$ & $65.1^{\mathrm{d}}$ & $378.8^{\mathrm{ab}}$ & 174.8 \\
\hline S. e. d & & 16.19 & 0.33 & 28.87 & 0.05 & 33.17 & 16.77 \\
\hline \multirow[t]{3}{*}{$\mathrm{P}$ value } & Cutting regime & $<.001$ & $<.001$ & 0.375 & $<.001$ & 0.091 & 0.12 \\
\hline & Fraction & 0.08 & $<.001$ & $<.001$ & $<.001$ & 0.002 & 0.14 \\
\hline & Cutting regime $\mathrm{x}$ Fraction & 0.47 & $<.001$ & 0.322 & $<.001$ & 0.906 & 0.06 \\
\hline
\end{tabular}

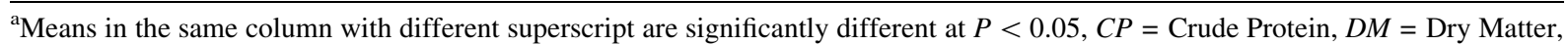
$N D F=$ Neutral Detergent Fibre, $A D F=$ Acid Detergent Fibre, $H E M=$ Hemicellulose 
The stem fraction consistently recorded higher ND and ADF compared to the leaf fraction.

The results on the gas production, DOM, short chain fatty acids and metabolizable energy of Cajanus cajan at different cutting regimes after initial establishment are presented in Table 3. There was a significant two-way interaction effect of cutting regime and botanical fraction on all parameters measured. The stem fractions generally produced higher gas at $24 \mathrm{~h}$ than the leaf fractions whiles the leaf fractions had higher DOM at all cutting regimes compared to the stem fractions. However, DOM decreased as the cutting regime increased. Metabolizable energy of the leaf fractions was also higher compared to the stem fraction with the highest obtained at harvest 12 and 16 WAP in the initial establishment.

Table 4 shows the results on the gas production, DOM, short chain fatty acids and metabolizable energy of Cajanus cajan at different cutting regimes after regrowth. There was a significant interaction effect between cutting regime and botanical fraction in all parameters analysed. The stem fraction generally produced more gas at $24 \mathrm{~h}$ with the highest $(21.8 \mathrm{~g} /$ $\mathrm{ml}$ ) gas production recorded in the stem fraction at 20 WAP in the regrowth. The DOM also increased with increasing cutting regime where the highest DOM was observed at 20 WAP regrowth.

\section{Discussions}

Growth and biomass yield of Cajanus cajan

Variations in the initial establishment and regrowth relative to plant height, number of branches and stem diameter in the current study is attributable to factors such as season and climatic conditions after harvest, or the presence of meristems and allocation of stored soluble carbohydrate for purposes of regrowth. Chiariello et al. (1991) reported that perennial plants employ a stress-tolerance strategy that includes short stature and high partitioning to belowground structures in unfavorable conditions. This adaptation may generally explain the lower plant height obtained in the regrowth compared to the initial establishment. Whilst the plant height diminished in the regrowth at all cutting regimes, branch number and stem diameter appreciated with a decline recorded only at 16 WAP relative to branch number. This phenomenon may have been occasioned by a possible efficient allocation of stored soluble carbohydrate towards increasing branch number and stem diameter. Additionally, the cutting at $50 \mathrm{~cm}$ stubble in all treatments may have resulted in the removal of the apical meristem thereby limiting the ability of the plants to grow vertically. Cajanus Cajan, like other legume has its apical meristem exposed and is easily removed at cutting or

Table 3 In vitro gas production, short chain fatty acids, metabolizable energy, digestible organic matter of Cajanus cajan as influenced by cutting regime at initial establishment

\begin{tabular}{|c|c|c|c|c|c|}
\hline \multirow[t]{2}{*}{ Cutting regime } & \multirow[t]{2}{*}{ Botanical fraction } & \multicolumn{4}{|l|}{ Parameters } \\
\hline & & GAS @ 24(g/ml) & $\begin{array}{l}\text { DOM } \\
(\mathrm{g} / \mathrm{Kg})\end{array}$ & $\begin{array}{l}\text { SCFA } \\
(\mathrm{mmol} / \mathrm{L})\end{array}$ & $\begin{array}{l}(\mathrm{MJ} / \mathrm{KgDM}) \\
\mathrm{ME}\end{array}$ \\
\hline \multirow[t]{2}{*}{ C 12} & Leaf & $16.8^{\mathrm{ab}}$ & $460^{\mathrm{a}}$ & $0.024^{\mathrm{ab}}$ & $10.8^{\mathrm{b}}$ \\
\hline & Stem & $15.3^{\mathrm{b}}$ & $365.2^{\mathrm{e}}$ & $0.022^{\mathrm{b}}$ & $8.01^{\mathrm{d}}$ \\
\hline \multirow[t]{2}{*}{ C 16} & Leaf & $15.4^{\mathrm{b}}$ & $440.8^{\mathrm{ab}}$ & $0.022^{\mathrm{b}}$ & $11.5^{\mathrm{a}}$ \\
\hline & Stem & $18.6^{\mathrm{a}}$ & $422.6^{\mathrm{bc}}$ & $0.026^{\mathrm{a}}$ & $8.5^{\mathrm{c}}$ \\
\hline \multirow[t]{2}{*}{ C 20} & Leaf & $15.1^{\mathrm{b}}$ & $415.1^{\mathrm{c}}$ & $0.021^{\mathrm{b}}$ & $11.6^{\mathrm{a}}$ \\
\hline & Stem & $16.4^{\mathrm{ab}}$ & $392.9^{\mathrm{d}}$ & $0.023^{\mathrm{ab}}$ & $8.8^{\mathrm{c}}$ \\
\hline S. e. d & & 0.67 & 6.16 & 0.0009 & 0.10 \\
\hline \multirow[t]{3}{*}{$\mathrm{P}$ value } & Cutting regime & 0.05 & $<.001$ & 0.05 & $<.001$ \\
\hline & Fraction & 0.02 & $<.001$ & 0.02 & $<.001$ \\
\hline & Cutting regime $\mathrm{x}$ Fraction & 0.002 & $<.001$ & 0.002 & 0.211 \\
\hline
\end{tabular}

${ }^{\mathrm{a}}$ Means in the same column with different superscript are significantly different at $P<0.05$, IVOMD $=$ In vitro organic matter digestibility, $S C F A=$ Short chain fatty acids, $M E=$ Metabolizable energy 
Table 4 In vitro gas production, short chain fatty acids metabolizable energy, digestible organic matter of Cajanus cajan as influenced by cutting regime at regrowth

\begin{tabular}{|c|c|c|c|c|c|}
\hline \multirow[t]{2}{*}{ Cutting regime } & \multirow[t]{2}{*}{ Botanical fraction } & \multicolumn{4}{|l|}{ Parameters } \\
\hline & & GAS @ $24(\mathrm{~g} / \mathrm{ml})$ & $\begin{array}{l}\text { DOM } \\
(\mathrm{g} / \mathrm{Kg})\end{array}$ & $\begin{array}{l}\text { SCFA } \\
(\mathrm{mmol} / \mathrm{L})\end{array}$ & $\mathrm{ME}(\mathrm{MJ} / \mathrm{KgDM})$ \\
\hline \multirow[t]{2}{*}{ RC 12} & Leaf & $17.2^{\mathrm{b}}$ & $428.3^{\mathrm{ab}}$ & $0.024^{\mathrm{b}}$ & $11.2^{\mathrm{a}}$ \\
\hline & Stem & $17.7^{\mathrm{b}}$ & $407.6^{\mathrm{b}}$ & $0.025^{\mathrm{b}}$ & $9.4^{\mathrm{b}}$ \\
\hline \multirow[t]{2}{*}{$\mathrm{RC} 16$} & Leaf & $15.8^{\mathrm{b}}$ & $418.9^{\mathrm{ab}}$ & $0.022^{\mathrm{b}}$ & $11.3^{\mathrm{a}}$ \\
\hline & Stem & $21.4^{\mathrm{a}}$ & $431.7^{\mathrm{ab}}$ & $0.031^{\mathrm{a}}$ & $8.5^{\mathrm{b}}$ \\
\hline \multirow[t]{2}{*}{ RC 20} & Leaf & $16.7^{\mathrm{b}}$ & $442.5^{\mathrm{a}}$ & $0.024^{\mathrm{b}}$ & $11.6^{\mathrm{a}}$ \\
\hline & Stem & $21.8^{\mathrm{a}}$ & $427.1^{\mathrm{ab}}$ & $0.031^{\mathrm{a}}$ & $9.4^{\mathrm{b}}$ \\
\hline S. e. d & & 0.87 & 7.85 & 0.001 & 0.41 \\
\hline \multirow[t]{3}{*}{$P$ value } & Cutting regime & 0.04 & 0.038 & 0.04 & 0.22 \\
\hline & Fraction & $<.001$ & 0.118 & $<.001$ & $<.001$ \\
\hline & Cutting regime $\mathrm{x}$ Fraction & 0.004 & 0.027 & 0.004 & 0.31 \\
\hline
\end{tabular}

${ }^{a}$ Means in the same column with different superscript are significantly different at $P<0.05, I V O M D=$ In vitro organic matter digestibility, $S C F A=$ Short chain fatty acids, $M E=$ Metabolizable energy

grazing (West and Nelson, 2017). Higher number of branches and stem diameter in the regrowth of Cajanus cajan qualifies the plant as a potential climate-smart crop with ability to maintain stable growth under drought conditions.

Higher biomass yield at 20 WAP in both initial establishment and regrowth conforms to what was obtained by Bode et al. (2018). On the average, the biomass yield in the regrowth was below $50 \%$ of the yield in the initial establishment. This could be due to a slow rate of photosynthesis after the initial cut since almost all the leaves were taken off at a cut height of $50 \mathrm{~cm}$ in the initial establishment. In the absence of adequate photosynthetic material, plants rely on stored soluble carbohydrate in the shoots and roots as the primary source of carbon to regrow (Deregibus et al., 1982). In the current study, it appeared the stored soluble carbohydrate could not stimulate rapid regrowth to maintain the amount of biomass obtained in the initial establishment. The regrowth period also coincided with the dry season leading to a water stress condition. Behboudian et al. (2001) reported decrease in plant height with corresponding decrease in biomass yield in chickpea (Cicer arietinum) when the plants were water stressed.

\section{Chemical composition of Cajanus cajan}

as affected by different cutting regimes

Higher mean DM recorded with longer cutting interval may be attributed to higher accumulation of structural tissues at harvest. This conforms to McDonald et al. (2002) who stated that, stage of maturity of forages is the most important factor that influences the DM yield and nutritional quality at harvest. The high $\mathrm{CP}$ levels in the leaf fractions agree with earlier reports from Tang et al. (2008) about the influence of botanical fraction and age on CP levels. As forages mature, the CP decreases and structural carbohydrates concentrations increase. The stems become tougher and more fibrous and protein and energy levels decrease. The $\mathrm{CP}$ contents reported in this study is within the range of $\mathrm{CP}$ values reported by Alexander et al. (2007) for 200 pigeon pea germplasms. With the exception of the stem fractions, the $\mathrm{CP}$ values reported in this study were within the range required for maintenance and growth of ruminants (NRC, 2007) and can therefore be used as feed supplement for ruminants. However, the CP contents in the stem fractions are within the minimum CP requirement $(60-80 \mathrm{~g} / \mathrm{kg}$ ) for sustenance of microbial growth (Weiss et al., 1992). The higher CP at $20 \mathrm{WAP}$ in the regrowth might have been influenced by the remobilization of nutrients from decomposed organic matter from shed leaves. Wedin and Russelle (2007) stated that, plants obtain most of their nutrients from the pool of dissolved nutrients in the soil. This solution is constantly being replenished from sources which include inputs like fertilizers and manure, decomposing organic matter and release of nutrients held weakly by the soil particles.

The trend in NDF, ADF and hemicellulose agrees with report of Lounglawan et al. (2014) that increasing 
the cutting regime increased the acid detergent fiber (ADF), neutral detergent fiber (NDF) and acid detergent lignin (ADL) in the plants. Lower NDF and ADF recorded in the leaf fractions compared to the stem could be attributed to the accumulation of vascular tissues in the development of the stem as it ages. The ash content obtained in this study is in agreement with Baars and Geleti (2000) who reported that mineral contents of plants declined during the maturing process due to natural dilution and translocation of nutrients from vegetative part to the root system. High ash in the leaf fractions is also an indication that the forages contain adequate minerals to support animal requirements.

In vitro gas production, short chain fatty acid, metabolizable energy, and digestible organic matter of Cajanus cajan

In vitro gas production, which is an indirect measure of microbial fermentation of feed and digestibility, was consistently higher in the stem fraction at all cutting regimes except at $12 \mathrm{WAP}$. This is as a result of the high dry matter accumulated in the stem relative to the leaf. Generally, DOM was higher in the leaf than the stem fraction in both the initial establishment and the regrowth despite the relatively low gas production in the leaf. Higher gas production from microbial fermentation with a corresponding low digestible organic matter suggest a potential inefficiency in the digestibility of the stem fraction in this study. The poor digestibility with high gas production may lead to higher emission of enteric GHG, especially, methane into the atmosphere when the stems are fed to ruminants. The feeding of stems of forages occurs when there is a high loss of leaves during storage and this is common in most developing countries during the dry season.

It was observed that the DOM, ME and SCFA all reduced with advance in age. This is attributable to the accumulation of vascular tissues in both the leaf and stem as the plants age. The middle lamella in the leaf is composed of vascular tissues usually lignified (Wilson and Hatfield 1997). This chemical structure of the middle lamella has been reported to slow down microbial fermentation leading to lower digestibility and metabolizable energy (Guo et al. 2001). The trend in SCFA may also be attributed to the extent of degradability of the plant as the cutting regime increases. The ME recorded in this study are higher than $7 \mathrm{MJ} / \mathrm{kgDM}$ and therefore suitable for meeting the maintenance requirement of beef and dairy cattle and rapidly growing calves (NRC 2007).

\section{Conclusion}

The results obtained in the study indicates that harvesting Cajanus cajan forages at different cutting regimes illicit different yield and quality responses in the Savanna Agro-Ecological Zone of Ghana. In the initial establishment, the highest plant height and biomass yield were recorded in the harvest at $20 \mathrm{WAP}$ whiles harvesting at 16 WAP had the highest number of branches and stem diameter. Dry matter increased as the cutting regime increased with the stem fractions recording higher dry matter contents. The leaf fraction of harvest at 12 WAP yielded the highest $\mathrm{CP}$ whiles the NDF and ADF concentrations increased as the cutting regime increased. In the regrowth however, harvest at $20 \mathrm{WAP}$ had the highest biomass yield, CP and ME. Increasing cutting regime also increased the concentrations of $\mathrm{CP}, \mathrm{NDF}$ and ADF. Meanwhile, biomass yield and chemical compositions were lower in the regrowth compared to the initial establishment.

Funding This research was funded by United State Agency for International Development (USAID)/Africa RISING project grant number GH 111B-19.

Data availability Available upon request and approval by authors.Consent for publication: All authors have consented to the publication of this manuscript.

\section{Declarations}

Conflict of interest The authors declare that they have no conflict of interest.

Open Access This article is licensed under a Creative Commons Attribution 4.0 International License, which permits use, sharing, adaptation, distribution and reproduction in any medium or format, as long as you give appropriate credit to the original author(s) and the source, provide a link to the Creative Commons licence, and indicate if changes were made. The images or other third party material in this article are included in the article's Creative Commons licence, unless indicated otherwise in a credit line to the material. If material is not included in the article's Creative Commons licence and your intended use is not permitted by statutory regulation or exceeds the permitted use, you will need to obtain permission directly from the copyright holder. To view a copy of this licence, visit http://creativecommons.org/licenses/by/4.0/. 


\section{References}

Agyare WA, Kombiok JM, Karbo N, Larbi A (2002) Management of pigeon pea in short fallows for crop-livestock production systems in the Guinea savanna zone of northern Ghana. Agrofor Syst 54(3):197-202

Alexander G, Ravi D, Ramakrishna RC, Saxena KB, Hanson J, Upadhyaya HD, Blummel M (2007) Forage yield and quality in pigeon pea germplasm lines. J SAT Agric Res 3(1):1-3

Ansah T, Wilkinson RG, Huntington J, Dei HK (2018) Effects of tropical browse plants on in vitro rumen protein degradability. Livestock Research for Rural Development $30(3)$

AOAC (Association of official analytical chemists) (1990) Official methods of analysis of Association of Official Analytical Chemists (16th edition), Washington DC

Baars R, Geleti D (2000) Production of panicum coloratum under varying stages of harvest low levels of nitrogen fertilizer and in combination with stylosanthes guianensis during establishment Year. Doctoral dissertation, Haramaya University.

Behboudian MH, Ma Q, Turner NC, Palta JA (2001) Reactions of chickpea to water stress: yield and seed composition. J Sci Food Agric 81(13):1288-1291

Bekele-Tessema A (2007) Profitable agroforestry innovations for eastern Africa: experience from 10 agroclimatic zones of Ethiopia, India, Kenya, Tanzania and Uganda. World Agroforestry Centre (ICRAF), Eastern Africa Region

Bidlack JE, Middick A, Shantz D, MacKown CT, Williams RD, Rao SC (2006) Weed control in a pigeon pea-wheat cropping system. Field Crop Res 96(1):63-70

Bode OO, Noah FA, Jacob OO (2018) Effects of spacing, cutting height and cutting interval on fodder yield and nutritional value of Cajanus Cajan. Int J Environ Agriculture Biotechnol 3(3):818

Chiariello NR, Gulmon SL, Mooney HA, Winner WE, Poll EJ (1991) Response of plants to multiple stresses. Academic Press 1:161-188

Corriher VA, Hill GM, Bernard JK, Jenkins TC, West JW, Mullinix JBG (2010) Pigeon peas as a supplement for lactating dairy cows fed corn silage-based diets. J Dairy Sci 93(11):5309-5317

Deregibus VA, Trlica MJ, Jameson VK (1982) Handbook of agricultural productivity. pp 315-344

Gowda CL, Saxena KB, Srivastava RK, Upadhyaya HD, Silim SN (2012) 16 Pigeon pea: From an Orphan to a Leader in Food Legumes. Biodiv Agricult Domesticat Evolut Sustain $1: 361$

Guo D, Chen F, Wheeler J, Winder J, Selman S, Peterson M, Dixon RA (2001) Improvement of in-rumen digestibility of alfalfa forage by genetic manipulation of lignin O-methyltransferases. Transgenic Res 10(5):457-464

Karbo N, Bruce J, Nyamekye AL, Fianu FK (1998) Effective management of pigeon pea (Cajanus cajan) in a crop/ livestock integrated farming system in northern Ghana. Ghana J Agricult Sci 31(2):161-168

Lounglawan P, Lounglawan W, Suksombat W (2014) Effect of cutting interval and cutting height on yield and chemical composition of King Napier grass (Pennisetum purpureum $\mathrm{x}$ Pennisetum americanum). APCBEE Proc 8:27-31
Marfo KO (1990) Food legumes improvement and the importance in the cropping systems of Northern Ghana. Proceedings of a workshop on improving farming systems in the interior savanna zone of Ghana. 24-26th April, 1990, pp. 98-107.

McDonald P, Edward RA, Greenhalgh JFD, Morgan GA (2002) Animal nutrition 6th pearson educational limited. Edinburgh, Great Britain pp544.

Menke KH, Steingass H (1988) Estimation of the energetic feed value obtained from chemical analysis and in vitro gas production using rumen fluid. Animal Res Develop 28:7-55

NRC (2007) Committee on the Nutrient Requirements of Small Ruminants, Board on Agriculture, Natural Resources, Division on Earth, and Life Studies. Nutrient requirements of small ruminants: sheep, goats, cervids, and new world camelids.

Payne RW, Murray DA, Harding SA, Baird DB, Soutar DM (2008) GenStat for Windows (11th Edition) Introduction. VSN International, Hemel Hempstead. P 204.

Sharma S, Agarwal N, Verma P (2011) Pigeon pea (Cajanus cajan L.): a hidden treasure of regime nutrition. J Funct Environ Botany 1(2):91-101

Shenkute B, Hassen A, Ebro A, Amen N (2013) Performance of Arsi-Bale kids supplemented with graded levels of pigeon pea in dry season in Mid Rift valley of Ethiopia. Afr J Agric Res 8(20):2366-2370

Tang SX, Gan J, Sheng LX, Tan ZL, Tayo GO, Sun ZH, Ren GP (2008) Morphological fractions, chemical composition and in vitro fermentation characteristics of maize stover of five genotypes. Animal 2(12):1772-1779

Theodorou MK, Williams BA, Dhanoa MS, McAllan AB, France J (1994) A simple gas production method using a pressure transducer to determine the fermentation kinetics of ruminant feeds. Anim Feed Sci Technol 48(3-4):185-197

Van Soest PV, Robertson JB, Lewis BA (1991) Methods for dietary fiber, neutral detergent fiber, and nonstarch polysaccharides in relation to animal nutrition. J Dairy Sci 74(10):3583-3597

Wedin DA, Russelle MP (2007) Nutrient cycling in forage production systems. Papers in Natural Res. 1:744

Weiss WP, Conrad HR, Pierre NS (1992) A theoretically-based model for predicting total digestible nutrient values of forages and concentrates. Anim Feed Sci Technol 39(1-2):95-110

West CP, Nelson CJ (2017) Managing grassland ecosystems. Forages an Introduct Grassland Agricult 1:357

Wilson JR, Hatfield RD (1997) Structural and chemical changes of cell wall types during stem development: consequences for fibre degradation by rumen microflora. Aust J Agric Res 48(2):165-180

Wolfson MM (2000) The response of forage plants to defoliation. In: Tainton, N. Pasture Management in South Africa (40-51). University of Natal press, South Africa.

Publisher's Note Springer Nature remains neutral with regard to jurisdictional claims in published maps and institutional affiliations. 